\title{
FLAKES UBI (FLABI) ALTERNATIF OLAHAN UBI JALAR
}

\section{UBI FLAKES (FLABI) ALTERNATIVE PROCESSED UBI JALAR}

\author{
Dwi Rahmawati ${ }^{\# 1}$, Arisanty Nur Setia Restuti ${ }^{* 2}$, Adhiningsih Yulianti*3 \\ ${ }^{\#}$ Jurusan Produksi Pertanian, Politeknik Negeri Jember \\ *Jurusan Kesehatan, Politeknik Negeri Jember \\ Jalan MastripPO BOX 164 Jember \\ Irahmawati@polije.ac.id \\ ªrisanty@polije.ac.id \\ 3adhiningsihapolije.ac.id
}

\begin{abstract}
Abstrak
Desa Pakis yang terletak Kecamatan Panti merupakan salah satu wilayah sentra penghasil ubi jalar di Kabupaten Jember. Namun, akibat minimnya pengetahuan para petani tentang pengolahan ubi jalar menjadikan tidak ada inovasi pengolahan hasil panen ubi jalar, sehingga komoditas tersebut memiliki nilai ekonomis/ nilai jual yang rendah. Untuk itu, inovasi teknologi pengolahan ubi jalar menjadi produk bernilai jual tinggi perlu disosialisasikan dan diterapkan kepada masyarakat. Kandungan gizi ubi jalar putih menjadi alasan ubi jalar putih menjadi pilihan tepat untuk inovasi sereal/ flakes ubi (FLABI) sebagai pengganti nasi. Ubi jalar putih mengandung pati/ karbohidrat yang paling tinggi diantara jenis ubi jalar yang lain sehingga sangat cocok apabila digunakan sebagai pengganti asupan karbohidrat. Selain itu, kandungan protein pada ubi jalar putih paling tinggi dibandingkan dengan jenis ubi yang lain. Kandungan air yang rendah menyebabkan ubi jalar putih lebih mudah ditepungkan dan diolah menjadi produk pangan lain dibandingkan ubi jenis yang lain. Harga ubi jalar putih juga relatif lebih murah dibandingkan harga ubi jalar jenis lain. Berdasarkan hal tersebut diatas menjadi dasar dipilihnya ubi jalar putih sebagai bahan baku produk inovatif sereal/ flakes ubi (FLABI). Dalam kegiatan pengabdian yang dilakukan oleh Tim Politeknik Negeri jember di Desa Pakis, masyarakat sangat antusias dan banyak bertanya tentang produk inovasi FLABI, selama ini mereka beranggapan bahwa ubi jalar hanya bisa diolah menjadi panganan seperti kripik atau jajanan tradisional seperti getuk. Produk inovasi FLABI ini diharapkan dapat menjadi salah satu solusi peningkatan nilai ekonomis ubi jalar putih.
\end{abstract}

Kata Kunci : Flabi, Inovasi, Ubi Jalar

Abstract

Pakis Village, which is located in Panti District, is one of the centers for sweet potato production in Jember Regency. However, due to the lack of knowledge of the farmers about sweet potato processing, there is no innovation in processing the sweet potato harvest, so that the commodity has a low economic value / selling value. For this reason, the innovation of sweet potato processing technology into high selling value products needs to be socialized and applied to the community. The nutritional content of white sweet potatoes is the reason white sweet potatoes are the right choice for innovating cereals / sweet potato flakes (FLABI) as a substitute for rice. White sweet potato contains the highest starch / carbohydrates among other types of sweet potato so it is very suitable when used as a substitute for carbohydrate intake. In addition, the protein content in white sweet potatoes is the highest compared to other types of sweet potato. The low water content makes white sweet potatoes easier to powder and process into other food products than other types of sweet potato. The price of white sweet potato is also relatively cheaper than the price of other types of sweet potato. Based on the foregoing, it is the basis for selecting white sweet potatoes as raw material for innovative cereals / sweet potato flakes (FLABI). In the service activities carried out by the Jember State Polytechnic Team in Pakis Village, the community was very enthusiastic and asked many questions about FLABI's innovative products, so far they thought that sweet potatoes could only be processed into snacks such as chips or traditional snacks such as getuk. This product of FLABI innovation is expected to be one of the solutions to increase the economic value of white sweet potato.

Keywords: Flabi, Innovation, Sweet Potatoes

\section{PENDAHULUAN}

Desa Pakis merupakan salah satu desa di Kecamatan Panti Kabupaten Jember yang berlokasi tepat dibawah kaki Gunung Argopuro. Sebagian besar wilayahnya merupakan kawasan perkebunan dan perbukitan. Sebagian besar penduduk Pakis berprofesi sebagai petani. Hal itu sesuai dengan keadaan alam yang wilayahnya banyak terdapat sawah. Desa Pakis memiliki luas wilayah total $1.578,584 \mathrm{Ha}$ yang terdiri dari wilayah pertanian sebesar 262.700 Ha, perumahan masyarakat 238.000 Ha dan wilayah perkebunan 1.050.000 Ha.

Jumlah penduduk di Desa Pakis sekitar 6799 warga yang yang terbagi atas empat dusun Pertelon, Gludug, Pakis, Cempaka, Kemundungan dan Ketajeg. Secara umum mata pencaharian masyarakat Desa 
Pakis adalah petani yang memiliki rata-rata pendapatan per bulan Rp. 700.000 sampai 1.000.000,-. Lokasi Desa Pakis dengan pusat kota terpisahkan jarak yang cukup jauh yaitu sebesar 27 $\mathrm{Km}$. Akses menuju kota kecamatan bisa ditempuh dalam waktu 15 menit dengan kendaraan motor. Sedangkan akses menuju kabupaten bisa ditempuh dalam waktu 40 menit dengan kendaraan bermotor.

Di Desa Pakis, terdapat lahan pertanian yang luas dan banyak ditanami palawija. Saat panen palawija, komoditi ubi jalar melimpah dan langsung dijual tanpa diolah, sehingga harganya sangat murah. Banyak petani yang menanam ubi jalar di Desa Pakis, sehingga wilayah tersebut menjadi sentra penghasil ubi jalar di Kabupaten Jember.

Inovasi teknologi pengolahan ubi jalar menjadi produk bernilai jual tinggi perlu disosialisasikan dan diterapkan kepada masyarakat. Tanaman Umbi-umbian merupakan tanaman dengan sumber karbohidrat yang sangat potensial untuk dikembangkan sebagai bahan pangan dengan berbagai olahan. Ubi jalar merupakan tanaman yang mudah ditemukan di pasar dengan harga relatif murah. Ada beberapa jenis ubi jalar yaitu ubi jalar putih, merah, ungu, kuning atau orange. Menurut data Badan Pusat Statistik jumlah produksi ubi jalar di Provinsi Jawa timur tahun 2016 sebesar 288.039 ton (BPS,2018). Beberapa tahun terakhir BPS (2018) produksi ubi jalar di daerah jember mencapai 93.720 kw. Namun, produksi ubi jalar yang meningkat tiap tahunnya tersebut tidak dapat dimanfaatkan dengan baik oleh petani. Biasanya, setelah melakukan proses pemanenan, mereka langsung menjual ubi jalar di pasar dengan harga yang murah sehingga nilai ekonomis ubi jalar menjadi menurun. Rata-rata pada 3 tahun terakhir, ubi jalar di daerah jember dijual dengan harga $\mathrm{Rp} 1.500$ - Rp 1.700/kg. Padahal, ubi jalar dapat dimanfaatkan dalam berbagai olahan yang dapat meningkatkan nilai ekonomis. Berikut ini merupakan kandungan gizi yang terdapat pada ubi jalar ${ }^{1}$ (tabel 1).

\begin{tabular}{lccc}
\multicolumn{4}{l}{ Tabel 1. Kandungan gizi ubijalar segar berdasarkan warna daging umbi. } \\
\hline Gizi & Ubi putih & Ubi kuning & Ubi ungu \\
\hline Pati (\%) & 28,79 & 24,47 & 22,64 \\
Gula reduksi (\%) & 0,32 & 0,11 & 0,30 \\
Lemak (\%) & 0,77 & 0,68 & 0,94 \\
Protein (\%) & 0,89 & 0,49 & 0,77 \\
Air (\%) & 62,24 & 68,78 & 70,46 \\
Abu (\%) & 0,93 & 0,99 & 0,84 \\
Serat (\%) & 2,79 & 2,79 & 3,00 \\
Vitamin C (mg/100 g) & 28,68 & 25,00 & 21,43 \\
Vitamin A (SI) a & 60,00 & $9.000,00$ & - \\
Antosianin (mg/100 g) & - & - & 110,51
\end{tabular}

Kandungan gizi ubi jalar putih menjadi alasan ubi jalar putih menjadi pilihan tepat untuk inovasi sereal/flakes ubi (FLABI). Ubi jalar putih mengandung pati/ karbohidrat yang paling tinggi diantara jenis ubi jalar yang lain sehingga sangat cocok apabila digunakan sebagai pengganti asupan karbohidrat. Selain itu, kandungan protein pada ubi jalar putih paling tinggi dibandingkan dengan jenis ubi yang lain. Kandungan air yang rendah menyebabkan ubi jalar putih lebih mudah ditepungkan dan diolah menjadi produk pangan lain dibandingkan ubi jenis yang lain. Harga ubi jalar putih juga relatif lebih murah dibandingkan harga ubi jalar jenis lain.

Flakes merupakan salah satu bentuk produk pangan yang umum dikonsumsi sebagai alternatif sarapan sebagai pengganti nasi ${ }^{2,3}$.Flakes yang saat ini beredar di pasaran terbuat dari serealia, yaitu gandum (wheat atau oat flakes), beras dan jagung (corn flakes $)^{4}$. Dengan semakin berkembangnya teknologi pengolahan pangan, maka flakes dapat dibuat dari berbagai macam bahan baku, salah satunya ubi jalar ${ }^{4}$. Flakes ubi jalar merupakan produk olahan instan ubi jalar yang praktis untuk dinikmati pada pagi hari sebagai makanan sarapan, umumnya dikonsumsi bersama susu cair sebagai sumber protein ${ }^{5}$.

Potensi ubi jalar yang ada di Desa Pakis dapat dimanfaatkan dengan baik sehingga dapat menjadi penggerak perekonomian masyarakat desa. Oleh karena itu, melalui program Pengabdian Kepada Masyarakat ini berupa kegiatan sosialisasi dan pelatihan pembuatan "Flakes Ubi (FLABI) Alternatif Olahan Ubi Bernilai Jual Tinggi bagi Petani di Desa Pakis Kecamatan Panti Kabupaten Jember"

Berdasarkan hasil survei awal dan wawancara dengan para petani ubi jalar dan kelompok wanita tani (KWT) "Rengganis". Maka dapat disimpulkan ada beberapa permasalah yang dihadapi petani ubi jalar, diantaranya :

1. Bagaimana meningkatkan nilai ekonomis ubi jalar bagi petani?

2. Bagaimana meningkatkan ketrampilan para petani dalam mengolah ubi jalar menjadiproduk inovasi FLABI?

Penerapan inovasi teknologi pengolahan ubi jalar menjadi sereal/ flakes (FLABI) diharapkan dapat menjadi solusi atas permasalahan yang dihadapi petani ubi jalar di desa Pakis.

\section{TARGET DAN LUARAN}

Program Pengabdian Masyarakat flakes ubi (FLABI) ini diharapkan dapat menjadi salah satu penerapan teknologi pengolahan dengan mengubah ubi jalar menjadi produk inovasi flakes ubi, sehingga dapat meningkatkan nilai ekonomis ubi jalar dan meningkatkan pendapatan bagi masyarakat di Desa Pakis. Setelah kegiatan sosisalisasi dan pelatihan ini diharapkan KWT rengganis dapat memproduksi dan memasarkan flakes ubi secara mandiri. Selain hal tersebut diatas ada beberapa luaran dan target capaian tim pelaksana yaitu pemberian alat pengolahan FLABI dan pengaplikasian hasil kegiatan oleh $15 \%$ anggota kelompok wanita tani. Selain itu kegiatan pengabdian masyarakat ini dipublikasikan melalui media massa 
online. Kegiatan pengabdian masyarakat ini nantinya diharapkan dapat menjadi bahan penulisan buku ajar yang berjudul pengolahan ubi jalar dan menghasilkan produk flakes ubi yang dapat didaftarkan sebagai HKI.

\section{METODE PELAKSANAAN}

Program pengabdian kepada masyarakat ini kami dilaksanakan di Desa Pakis Kecamatan Panti. Program ini dilaksanakan selama 6 bulan di mulai bulan Juli - Desember.

Kegiatan pengabdian kepada masyarakat ini melibatkan KWT Rengganis sebagai petani ubi jalar serta komponen institusi dari Perguruan Tinggi, yaitu dosen dan mahasiswa sebagai pendamping kegiatan. Adapun mahasiswa yang terlibat dala kegiatann ini berjumlah 2 orang. Tahap pelaksanaan program pengabdian dapat dilihat pada tabel 2

Tabel 2. Tahapan pelaksanaan pengabdian masyarakat FLABI

\begin{tabular}{|c|c|}
\hline $\begin{array}{l}\text { Pertemuan } \\
\text { ke }\end{array}$ & Kegiatan \\
\hline 1 & $\begin{array}{l}\text { Koordinasi antara tim pelaksana } \\
\text { dengan mitra untuk mengadakan } \\
\text { kegiatan sosialisasi terkait potensi } \\
\text { ubi jalar menjadi panganan olahan } \\
\text { bernilai jual tinggi }\end{array}$ \\
\hline 2 & $\begin{array}{l}\text { Kegiatan sosialisasi terkait potensi } \\
\text { ubi jalar menjadi panganan olahan } \\
\text { bernilai jual tinggi. } \\
\text { Kegiatan sosialisasi pengolahan ubi } \\
\text { jalar menjadi produk inovasi flakes } \\
\text { ubi (FLABI) }\end{array}$ \\
\hline 3 & $\begin{array}{l}\text { Kegiatan pelatihan pembuatan } \\
\text { flakes ubi diawali dengan } \\
\text { memberikan } \\
\text { menggunakan metode diskusi } \\
\text { tentang tujuan mempelajari } \\
\text { pembuatan flakes ubi sebagai } \\
\text { inovasi hasil panen ubi. Membahas } \\
\text { materi dengan menggunakan slide } \\
\text { presentasi tentang prosedur - } \\
\text { prosedur pengolahan ubi menjadi } \\
\text { sereal/flakes. }\end{array}$ \\
\hline $4 \& 5$ & $\begin{array}{l}\text { Peserta melakukan praktek } \\
\text { pengolahan ubi menjadi flakes ubi. }\end{array}$ \\
\hline
\end{tabular}

IV. HASIL DAN PEMBAHASAN

Kegiatan Pengabdian "Flakes Ubi

(FLABI) Alternatif Olahan Ubi Bernilai Jual Tinggi bagi Petani di Desa Pakis Kecamatan Panti Kabupaten Jember" dilaksankan dengan tahapan sebagai berikut :

\subsection{Observasi dan wawancara}

Setelah melakukan wawancara dan observasi dengan masyarakat sasaran didapatkan permasalahan yang dihadapi masyarakat sasaran adalah tingginya produksi ubi jalar, rendahnya pengetahuan petani dan rendahnya harga jual ubi jalar. Permasalahan tersebut diharapkan dapat diatasi dengan inovasi berupa pengolahan ubi jalar menjadi flakes ubi untuk meningkatkan nilai ekonomis ubi jalar dan mengatasi produksi ubi jalar yang tinggi.

\subsection{Koordinasi dengan mitra}

Kegiatan ini meliputi Koordinasi antara tim pelaksana dengan mitra untuk mengadakan kegiatan sosialisasi terkait potensi ubi jalar menjadi panganan olahan bernilai jual tinggi.

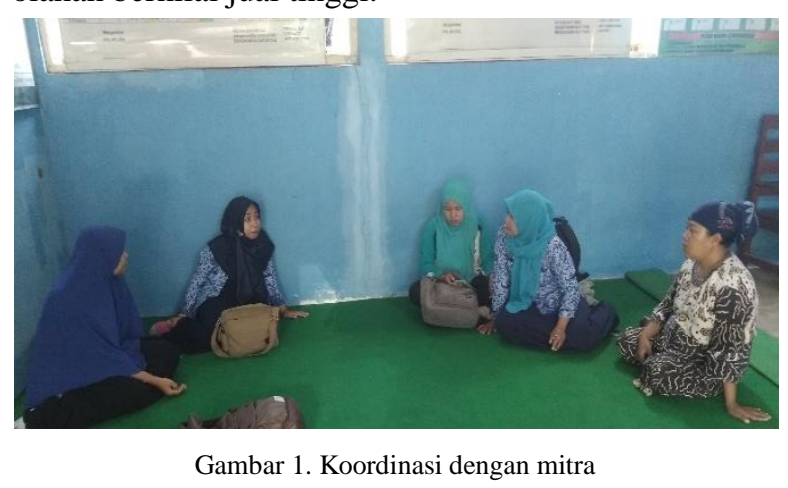

\subsection{Pelaksanaan sosialisasi}

Kegiatan ini meliputi sosialisasi terkait potensi ubi jalar putih menjadi panganan olahan untuk meningkatkan nilai ekonomis ubi jalar. Selain itu kegiatan ini juga dimaksudkan untuk meningkatkan rendahnya pengetahuan kelompok wanita tani "Rengganis" terkait pengolahan ubi jalar putih. Salah satu inovasi pengolahan ubi jalar putih adalah dengan mengolahnya menjadi FLABI.

Peserta yang hadir dalam sosialisasi ini sangat antusias dan banyak bertanya tentang produk inovasi FLABI, selama ini mereka beranggapan bahwa ubi jalar hanya bisa diolah menjadi panganan seperti kripik atau jajanan tradisional seperti getuk. Produk inovasi FLABI ini diharapkan dapat menjadi salah satu solusi peningkatan nilai ekonomis ubi jalar putih.

\subsection{Pelaksanaan uji coba rasa FLABI}

Kegiatan ini meliputi uji coba rasa dan bentuk FLABI kepada mitra dan masyarakat sekitar desa Pakis. Hal ini dimaksudkan untuk menyesuaikan selera dan bentuk yang diinginkan oleh masyarakat agar produk ini dapat diterima pasar.

Pada tahap ini yang dilibatkan bukan hanya mitra akan tetapi anak - anak disekitar lokasi mitra. Dari kegiatan ini didapatkan bahwa produk FLABI disukai baik anak - anak maupun dewasa. Menurut yang mencoba FLABI dapat di konsumsi menggunakan susu segar ataupun sebagai camilan. 


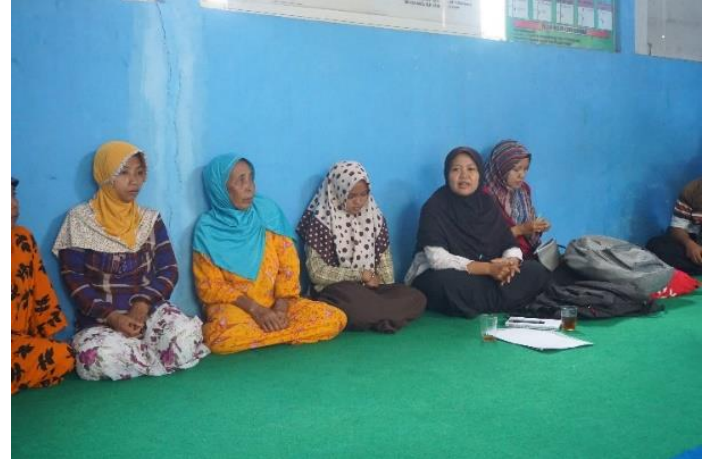

Gambar 2. Pelaksanaan sosialisasi FLABI

\subsection{Pelaksanaan Pelatihan pembuatan FLABI}

Kegiatan ini meliputi memberikan pelatihan pembuatan produk inovasi ubi jalar FLABI. Seluruh anggota kelompok wanita tani dilibatkan dalam kegiatan ini mulai menimbang bahan, mencampur bahan hingga menjadi adonan, mencetak sampai dengan memanggang FLABI. Mitra sangat antusias dengan pelatihan ini karena menurut mereka hal ini menjadi salah satu inovasi pengolahan ubi jalar putih yang mempunyai nilai jual paling rendah .

Adapun tahapan pelatihan pembuatan FLABI meliputi : Persiapan bahan, alat prosedur pembuatan FLABI. Alat yang dibutuhkan adalah timbangan, pengaduk, waskom, gelas ukur, oven, rolling pin, plastik alas, cetakan berbagai macam bentuk, loyang untuk memanggang. Bahan penunjang yang dibutuhkan adalah pengoles loyang secukupnya.

Tabel 3. Bahan pembuatan FLABI

\begin{tabular}{ll}
\hline \multicolumn{1}{c}{ Bahan } & Jumlah \\
\hline Tepung Ubi & $100 \mathrm{~g}$ \\
Tepung Tapioka & $20 \mathrm{~g}$ \\
Tepung Maizena & $20 \mathrm{~g}$ \\
Bubuk Cokelat & $30 \mathrm{~g}$ \\
Gula & $50 \mathrm{~g}$ \\
Susu Bubuk & $30 \mathrm{~g}$ \\
Air & $20 \mathrm{ml}$ \\
Garam & $1 \mathrm{sdt}$ \\
\hline
\end{tabular}

\subsection{Pemberian Peralatan penunjang pengolahan FLABI}

Kegiatan ini meliputi pemberian peralatan penunjang untuk pengoahan FLABI. Hal ini ditujukan agar mitra dapat memproduksi FLABI secara mandiri. Adapun peralatan penunjang yang diberikan adalah pemanggang (oven gas), tabung gas, kontainer tempat menyimpan perlatan, serbet, pencetak FLABI, rolling pin, waskom, solet, loyang untuk memanggang, dan timbangan digital.

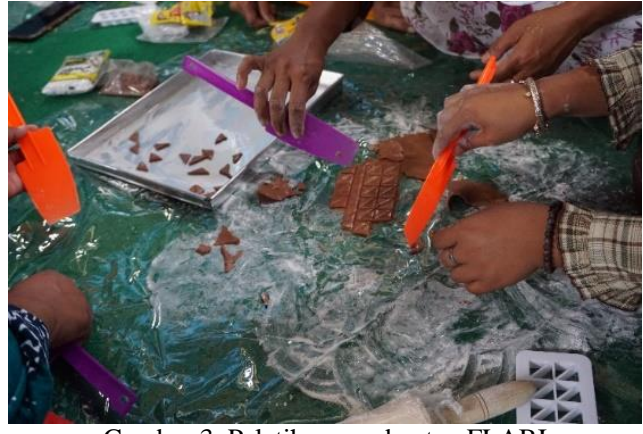

Gambar 3. Pelatihan pembuatan FLABI

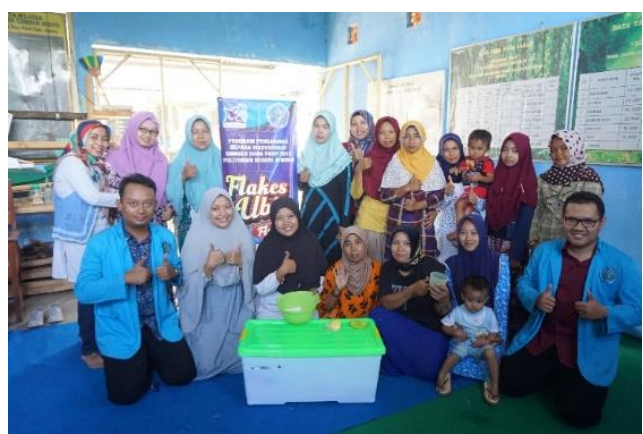

Gambar 4. Penyerahan alat penunjang pengolahan

\section{KESIMPULAN}

Berdasarkan hasil kegiatan yang telah dilakukan dapat disimpulkan bahwa koordinasi selalu dilakukan dengan mitra sehingga terjalin hubungan yang lebih baik. Di samping itu, kegiatan pengabdian ini mampu meningkatkan pengetahuan mitra terkait pengolahan ubi jalar. Pelatihan pembuatan produk inovasi pengolahan ubi yang disebut FLABI juga diikuti dengan antusias oleh anggota kelompok tani wanita Rengganis. Dalam kegiatan juga telah diserahkan beberapa alat penunjang pembuatan FLABI seperti oven.

\section{UCAPAN TERIMA KASIH}

Pengabdian Masyarakat dilaksanakan dengan sumber dana PNBP Politeknik Negeri Jember.

\section{DAFTAR PUSTAKA}

[1] Ginting, E., J.S. Utomo, R. Yulifianti, dan M.Jusuf. 2011. Potensi Ubijalar Ungu sebagai Pangan Fungsional. Jurnal Iptek Tanaman Pangan Vol. 6 No.1 Halaman 116-138.

[2] Felicia, A. 2006. Pengembanangan Produk Sereal Sarapan Siap Santap bebasis Sorghum. Skripsi. Fakultas Teknologi Pertanian. Institut Pertanian Bogor.

[3] Pangestika, R. 2017. Formulasi Flakes Berbahan Dasar Ubi Ungu (Ipomea Batatas L.) Dan Kacang Merah (Phaseolus Vulgaris L.) Tinggi Serat Pangan Dan Rendah Lemak. Skripsi. Departemen Gizi Masyarakat. Fakultas Ekologi Manusia. Institut Pertanian Bogor.

[4] Yanis,M., S. Aminah, Y. Handayani, dan T. Ramdhan. 2016. Uji Organoleptik Formula Flakes dari Pasta Ubi Jalar dengan Penambahan Tepung Jalejo. Prosiding Seminar Hasil Penelitian Tanaman Aneka Kacang dan Umbi 2016. Halaman 603 - 610.

[5] Saleha, NM. 2016. Optimasi Formulasi Flakes Berbasis Tepung Ubi Cilembu Tepung Tapioka Serta Tepung Kacang Hijau Menggunakan Aplikasi Design Expert Metode Mixture DOptimal. Skripsi. Program Studi Teknologi Pangan. Fakutlas Teknik. Universitas Pasundan. 